\title{
Financial and Economic Features of Technical Re-equipment of the Workshop Machine-Building Enterprise
}

\author{
Elvira Distantovna Khisamova ${ }^{1}$, Svetlana Mazgutovna Nuryyakhmetova ${ }^{1} \&$ Gulnara Damirovna Kayumova ${ }^{1}$ \\ ${ }^{1}$ Department of Economics, Institute of Management, Economics and Finance, Kazan Federal University, Kazan, \\ Russia \\ Correspondence: Elvira Distantovna Khisamova, $\mathrm{PhD}$ in Economics, Institute of Management, Economics and \\ Finance, Kazan Federal University, Kazan, Russia. Tel: 7-917-276-4076. E-mail: ela_76@mail.ru
}

Received: August 5, 2020

doi:10.5430/ijfr.v11n5p434
Accepted: September 15, $2020 \quad$ Online Published: October 4, 2020

URL: https://doi.org/10.5430/ijfr.v11n5p434

\begin{abstract}
One of the urgent problems of modern industrial enterprises is the problem of their technical development. The most common direction of technical development is the technical re-equipment of industrial enterprises. This is a very long and costly process, requiring both from the management of the enterprise and from its employees of high qualification, the ability, and skills to make quick decisions and predict the outcomes of these decisions. Currently, the market for technical and technological equipment is represented by many kinds of different industrial machines, aggregates, mechanisms of different manufacturing firms, different levels of complexity, productivity, energy intensity, and, of course, different costs. The analysis of the market, the choice of suppliers of production equipment, the formulation of terms of delivery and payment, installation, assembly, and installation of equipment at the enterprise, commissioning and subsequent technical support are all elements of the process of renewal of fixed assets called technical re-equipment.

Technical re-equipment includes raising the technological level of production, which includes the use of additional new equipment (both in the case of physical and moral obsolescence).

During this event, either modified tools will be used in the production of old products, or the quality of the products will change, or a completely new product will be produced, or all taken together. In addition, the concept of technical re-equipment can include the re-qualification of personnel during the re-equipment process and bringing technologies in line with environmental norms and standards.
\end{abstract}

Keywords: technical re-equipment, modernization, investment efficiency, equipment quality, labor productivity

\section{Introduction}

The definitions of "technical modernization", "technical re-equipment" are reflected in the works of such authors as L. Kurakov, A. Azrilian, V.V. Ostroshenko, B. A. Raisenberg, L. Sh. Lozovsky, A P. Bochkov, E. B. Staroduptseva, D. P. Gasyuk, G. N. Sokolova, Yu. Lyubimtsev, E. Kallagov, S. F. Pokropivny, M. A. Vilensky, B. P. Sharnopolsky, and in many domestic and foreign dictionaries, encyclopedias, textbooks, scientific articles and regulations.

An analysis of the definitions of the term "modernization" does not allow us to single out a clearly formulated and unified opinion among economists. Many economists (V.V. Ostoshenko, L. Kurakov, A. N. Azrilian, B. A. Raisenberg, L. Sh. Lozovsky, E. B. Starodubtseva) associate modernization with updating the object, bringing it into line with technical requirements and norms (physical deterioration) (Modernization: a multi-subject. scientific encyclical \& Azriliyan, 2000).

The definition of "technical re-equipment" is more often found in the literature. A set of measures aimed at improving the technical level of production through the introduction of more advanced equipment, technology and the organization of work in the main and auxiliary production (Reisenberg, 2006; Susaraie \& Sayahi, 2018).

The technical re-equipment of enterprises involves a set of steps to enhance the technical and economic level of individual industries, workshops, and sections. These steps are based on the introduction of advanced equipment and technology, mechanization and automation of production, modernization, and replacement of obsolete and physically worn-out equipment with new, more efficient ones. The steps also include boosting plant-wide household and support services (Perez, 2005). 
Re-equipment of existing enterprises. Technical re-equipment - a set of measures to improve the technical and economic level of individual industries, workshops, and sections based on the introduction of advanced equipment and technology, mechanization and automation of production, modernization and replacement of obsolete and physically worn-out equipment, new more productive, as well as to improve the general factory household and support services (Azriliyan, 2002).

Thus, by technical re-equipment of an enterprise, we understand a set of measures to increase the technical level of individual production facilities following modern requirements by introducing new equipment and technology, mechanizing and automating production processes, modernizing and replacing obsolete equipment, and improving organization and structure of production, is aimed at increasing the intensification of production, increasing production capacities, improving the quality of products, increasing labor productivity and reducing costs (Yasin, 2009).

\section{Methods}

For the implementation of the investment project for the technical re-equipment and modernization of the production halls of a machine-building enterprise, a decision was made to allocate capital investments for 15,000 thousand rubles. Distribution of expected cash receipts by year in thousand rubles: 1 year - 4260; 2 year - 4667.6; 3 year 5270.6; 4 year - 4957.9; 5 year - 3020.2. The discount rate is set at $14 \%$.

For technical re-equipment of the enterprise's shops, the management decided to purchase the equipment at one of the machine-tool enterprises, where its production was mastered. The actual stock of machine operating time $(\mathrm{Fq})$ is 4015 , the machine load factor $(\mathrm{Rz})$ is 0.73 .

Table 1. Economic indicators of power machines

\begin{tabular}{llll}
\hline Index & Name of indicator & \multicolumn{2}{l}{ Indicator value } \\
\cline { 3 - 4 } & & base & new \\
\hline 1 & Machine price, rub. & 8000 & 10000 \\
\hline 2 & Operating expenses, rub / h & 1,64 & 1,73 \\
\hline
\end{tabular}

The production program of the enterprise's workshop plans to produce 200,000 products per month (25.4 business days per month) using new equipment.

The operating mode is 4-shift, shift duration of 6 hours.

Planned downtime of equipment for repair will amount to $3 \%$ of the operating time stock, the distance between adjacent jobs is 1.6 meters, breaks - 20 minutes.

Norms of time for operations of the technological process (in seconds) will be: 1 operation - 40; 2 operation - 32; 3 operation - 28; 4 operation - 19; 5 operation - $51 ; 6$ operation - 82 .

As a result of the planned measures for the technical re-equipment of the workshops, an increase in labor productivity is expected; technical improvement of jobs and, accordingly, savings in the number of workers; reduction of losses of working time, which will increase the efficiency of workers.

The results of the workshop №1 in the base year are presented in Table 2.

Table 2

\begin{tabular}{llll}
\hline \multirow{2}{*}{$\begin{array}{l}\text { Workshops } \\
\text { name }\end{array}$} & $\begin{array}{l}\text { Volume of production, } \\
\text { thousand rubles }\end{array}$ & \multicolumn{2}{l}{ The number of workers } \\
\cline { 3 - 4 } & main & auxiliary \\
\hline Shop №1 & 323 & 59 & 17 \\
\hline
\end{tabular}

The number of key workers is growing in proportion to the increase in output. The number of auxiliary workers at $1 \%$ of the growth volume increases by $0.4 \%$.

The change in output in the workshops is as follows (Table 3): 
Table 3

\begin{tabular}{|c|c|c|c|c|}
\hline \multirow[t]{2}{*}{$\begin{array}{l}\text { Name of } \\
\text { workshops }\end{array}$} & \multicolumn{2}{|c|}{$\begin{array}{l}\text { Volume of production, } \\
\text { thousand rubles }\end{array}$} & \multicolumn{2}{|c|}{ The number of workers } \\
\hline & plan & report & plan & report \\
\hline Shop №1 & 350 & 320 & - & 75 \\
\hline Shop №2 & 870 & 900 & 120 & 122 \\
\hline Shop №3 & 280 & 310 & 60 & 60 \\
\hline
\end{tabular}

In 1 workshop, a group photo of working time was conducted. For 50 workers, a balance of working time was compiled (Table 4).

Table 4

\begin{tabular}{lll}
\hline Time spent & Duration, min & \\
\cline { 2 - 3 } & Actual & $\begin{array}{l}\text { Normativ } \\
\mathrm{e}\end{array}$ \\
\hline Preparatory work & 30 & 21 \\
\hline Operational work & - & 415 \\
\hline Workplace Maintenance & 26 & 17 \\
\hline Leisure and personal needs & 24 & 27 \\
\hline Loss of working time due to the fault of the worker & 18 & - \\
\hline Total balance & 480 & 480 \\
\hline
\end{tabular}

At the beginning of the planning period, the available fleet of machines at this plant consisted of 107 units. In the planning period from September 1, it is planned to replace 6 machines and to upgrade 9 machines from July 1. Compared to old machines, new machines increase productivity by $60 \%$, and modernized machines by $65 \%$. The productivity of old machines remains in the planning period at the level of the base period. The estimated number of workers according to the plan in table 2 , and the proportion of machine workers in the total number of employees is $70 \%$.

\section{Results}

1. To justify the choice of an investment project for the technical re-equipment and modernization of workshops, the enterprises calculated the net present value, which turned out to be more than 0 :

$$
\begin{array}{r}
\mathrm{NPV}=4260 /(1+0,14)+4667,6 /(1+0,14) \times(1+0,14)+5270,6 /(1+0,14) \times(1+0,14) \times(1+0,14)+4957,9 /(1+0,14) \times(1+0,14) \times \\
(1+0,14) \times(1+0,14)+3020,2 /(1+0,14) \times(1+0,14) \times(1+0,14) \times(1+0,14) \times(1+0,14)-15000=15391,0
\end{array}
$$

Thousand roubles. $-15000=391.0$ thousand roubles

The project profitability index was more than 1 :

$$
\text { PI }=15391,0 / 15000=1,026
$$

Conclusion: the investment project should be implemented.

Let us justify the choice of acquiring equipment for the production line organization (Khisamova, 2017). Relative quality indicators (qi) are equal to 1 or more than 1. The relative values of the new machine are at the base level, and for the majority exceed them. 
Table 5. Calculation of relative and integrated quality indicators aggregate machine

\begin{tabular}{|c|c|c|c|c|c|c|}
\hline \multirow[t]{2}{*}{ Index } & \multirow[t]{2}{*}{ Name of indicator } & \multicolumn{2}{|c|}{ Indicator value } & \multirow{2}{*}{$\begin{array}{l}\text { Relative } \\
\text { quality indica } \\
\text { tors (qi) }\end{array}$} & \multirow{2}{*}{$\begin{array}{l}\text { Weight } \\
\text { ratio (ri) }\end{array}$} & \multirow{2}{*}{$\begin{array}{l}\text { Comprehensive } \\
\text { product quality } \\
\text { index, Kcomp }\end{array}$} \\
\hline & & base (Рiб) & new $(\mathrm{Pi})$ & & & \\
\hline \multicolumn{7}{|c|}{ 1. Indicators of appointment } \\
\hline 1.1 & Productivity, pcs / h & 12 & 14 & 1,17 & 10 & 11,7 \\
\hline 1.2 & $\begin{array}{l}\text { Processing accuracy - } \\
\text { non-flatness over a length of } \\
500 \mathrm{~mm}, \mathrm{~mm}\end{array}$ & 0,06 & 0,05 & 1,2 & 8 & 9,6 \\
\hline 1.3 & $\begin{array}{l}\text { Processing accuracy } \\
\text { non-parallelism and } \\
\text { non-perpendicularity af } \\
\text { planes over a length of } 100 \\
\mathrm{~mm}, \mathrm{~mm}\end{array}$ & 0,03 & 0,025 & 1,2 & 8 & 9,6 \\
\hline 1.4 & $\begin{array}{l}\text { The purity of the processing } \\
\text { planes, microns }\end{array}$ & 3,0 & 2,5 & 1,2 & 8 & 9,6 \\
\hline \multicolumn{7}{|c|}{ 2. Indicators of reliability and durability } \\
\hline 2.1 & $\begin{array}{l}\text { Service life before major } \\
\text { repairs, years }\end{array}$ & 8 & 10 & 1,25 & 9 & 11,3 \\
\hline 2.2 & Warranty period, years & 1,5 & 2 & 1,33 & 5 & 6,7 \\
\hline \multicolumn{7}{|c|}{ 3. Indicators of manufacturability } \\
\hline 3.1 & $\begin{array}{l}\text { Coefficient of assembly } \\
\text { (blockiness) of the machine, } \\
\text { units }\end{array}$ & 1,0 & 1,0 & 1,0 & 4 & 4,0 \\
\hline 3.2 & $\begin{array}{l}\text { Specific labor input, } \\
\text { normo-h / kW }\end{array}$ & 390 & 360 & 1,08 & 5 & 5,4 \\
\hline 3.3 & $\begin{array}{l}\text { Specific material } \\
\text { consumption, } \mathrm{kg} / \mathrm{kW}\end{array}$ & 800 & 780 & 1,02 & 5 & 5,1 \\
\hline \multicolumn{7}{|c|}{ 4. Ergonomic indicators } \\
\hline 4.1 & $\begin{array}{l}\text { Conformity of design with } \\
\text { safety regulations, points }\end{array}$ & 5 & 5 & 1,0 & 8 & 8,0 \\
\hline 4.2 & Noise level, decibels & 80 & 75 & 1,07 & 6 & 6,4 \\
\hline \multicolumn{7}{|c|}{ 5. Aesthetic indicators } \\
\hline 5.1 & $\begin{array}{l}\text { Appearance, } \begin{array}{l}\text { quality of } \\
\text { decoration, } \\
\text { points }\end{array} \\
\text { packaging, }\end{array}$ & 4 & 5 & 1,25 & 5 & 6,3 \\
\hline \multicolumn{7}{|c|}{ 6. Indicators of standardization and unification } \\
\hline 6.1 & $\begin{array}{l}\text { Applicability of unified and } \\
\text { standard assembly units, } \%\end{array}$ & 60 & 65 & 1,08 & 8 & 8,6 \\
\hline \multicolumn{7}{|c|}{ 7. Patent law indicators } \\
\hline 7.1 & $\begin{array}{l}\text { The indicator of patent } \\
\text { protection, units }\end{array}$ & 0,13 & 0,15 & 1,15 & 6 & 6,9 \\
\hline 7.2 & $\begin{array}{l}\text { The indicator of patent } \\
\text { purity, units }\end{array}$ & 1,0 & 1,0 & 1,0 & 5 & 5,0 \\
\hline Total: & & & & & 100 & 114,2 \\
\hline
\end{tabular}


Comprehensive quality score Kcomp $=114.2 / 100,0=1,14$.

Conclusion: the new machine is superior to the base in its quality characteristics.

A generalized (integral) indicator of the quality of Ki of the base and new machines (Kib., Kin.) And the quality level $\mathrm{K}$ of the new machine:

$$
\begin{gathered}
\text { E ps base }=12 \times 4015 \times 0.73 \times 8=281371 \text { pieces } \\
\text { E ps new }=14 \times 4015 \times 0.73 \times 10=410333 \text { pieces } \\
\text { I pp base }=1.64 \times 4015 \times 0.73 \times 8=38454 \text { rubles } \\
\text { I pp new }=1.73 \times 4015 \times 0.73 \times 10=50705 \text { rubles } \\
\text { K iб. }=281371 / 8000+38454=6.06 \text { pieces } / \text { rubles } \\
\text { K in. }=410333 / 10000+50705=6.76 \text { pieces } / \text { rubles } \\
\text { K }=6.76 / 6.06=1,12
\end{gathered}
$$

Slight difference in values Kcomp and $\mathrm{K}$ indicates a sufficiently high accuracy in evaluating the quality of the machine.

The total useful effect per unit of cost for the creation and operation of a new machine is greater (6.67), relative to the base, as evidenced by a comprehensive quality indicator (1.12).

The calculation of the effectiveness of the organization of continuous production in the framework of the project for the technical re-equipment and modernization of production facilities.

Production line cycle:

$$
r=33446.72 / 200000=0,167 \text { minutes or } 10 \text { seconds }
$$

Effective time fund:

$$
\begin{gathered}
\text { Teff }=4 \times(25,4 \times 6 \times 60-25,4 \times 20-25,4 \times 6 \times 60 \times 0,03)=33446,72 \text { minutes } \\
8361.68 \times 4=33446.72
\end{gathered}
$$

Number of jobs in each operation:

$$
\mathrm{m}=40 / 10+32 / 10+28 / 10+19 / 10+51 / 10+82 / 10=25 \text { work places }
$$

Production line length:

$$
\mathrm{L}=1.6 \times 25=40 \text { meters }
$$

Production line speed:

$$
\mathrm{V}=1.6 / 10=0.16 \text { meters } / \text { second }
$$

Determination of the expected increase in labor productivity due to structural changes in the volume of output and the number of workers; modernization and replacement of equipment; improved use of working time.

Increasing labor productivity due to structural changes in the volume of output and changes in the number of workers.

Define the planned increase in output in workshop 1 in \%:

350: $323=1.08=8 \%$;

The number of key employees of the 1st workshop in the planning period will be:

59 person* $1,08=64$ person

The number of auxiliary workers 1 workshop in the planning period will be:

$8 \% * 0.4=3.2 \%$;

17 person $* 1,032=17$ person

The total number of employees of 1 workshop in the planning year is equal to:

64 person +17 person $=82$ person 
Table 6

\begin{tabular}{|c|c|c|c|c|c|c|}
\hline & $\begin{array}{l}\text { Production per } 1 \\
\text { worker, thousand } \\
\text { rubles }\end{array}$ & $\begin{array}{l}\text { Production per } 1 \\
\text { worker, thousand } \\
\text { rubles }\end{array}$ & plan /report & Indices & & \\
\hline Work shop & plan & report & growth & variable & constant & structural \\
\hline 1 & 4,268 & 4,267 & $99,4 \%$ & & & \\
\hline 2 & 7,250 & 7,377 & $101,8 \%$ & & & \\
\hline 3 & 4,667 & 5,167 & $110,7 \%$ & & & \\
\hline Total & 5,736 & 5,953 & $103,8 \%$ & 1,038 & 1,031 & 1,006 \\
\hline
\end{tabular}

In the whole enterprise, the labour productivity of workers rose $3.2 \%$ against the plan (variable composition index 1.032).

The constant composition index is:

$$
\frac{0.994 \times 75+1.018 \times 122+1.107 \times 60}{75+122+60}=1.031
$$

The structural index is:

1,032:1,031=1,001.

Increasing labor productivity through the modernization and replacement of equipment.

$$
\begin{gathered}
\text { Эмод. }=\left(100-\frac{107 \times 100}{(98 \times 100)+(9 \times 165)} \times 100\right) \times \frac{6}{12}=2,6 \% \\
\text { Эзам.. }=\left(100-\frac{107 \times 100}{(101 \times 100)+(6 \times 160)} \times 100\right) \times \frac{4}{12}=1.1 \% \\
\text { Эчис.. }=\frac{262 \times 70 \times(2,6+1,1)}{100 \times 107}=\text { бчел. }
\end{gathered}
$$

Increasing labor productivity by improving the use of shift working hours.

$$
\Pi n m=\frac{\text { Tonн }- \text { Ton } \phi}{\text { Ton } \phi} \times 100 \%=\frac{415-382}{382}=8,6 \%
$$

In total, labor productivity should grow:

Due to modernization and replacement of equipment $\Pi \mathrm{T}=3,2 \%$;

$$
\Pi T=\frac{6}{262-6} \times 100=2,64 \%
$$

Due to modernization and replacement of equipment; 


$$
\Pi T=\frac{8.6 \times 50}{262}=1.64 \%
$$

By improving the use of shift working time

Total growth:

$$
\begin{gathered}
\Pi \mathrm{T}=1.032 * 1.026 * 1.016=1.075=7.5 \% \\
\Pi \mathrm{T}=3.2 \%+2.64 \%+1.64 \%=7.5 \%
\end{gathered}
$$

\section{Summary}

As a result, we found that the following factors ensure the growth of labor productivity and population savings:

- Due to structural changes in the volume of production by workshops, labor productivity increased by $3.2 \%$, while at the same time the number decreased by five people .;

- Due to modernization and replacement of machine tools, labor productivity increased by $2.64 \%$, and the number decreased by six people.;

- Due to the improvement in the use of working hours of the shift, labor productivity increased by $1.64 \%$.

As a result of the actions of all factors, labor productivity increased by $7.5 \%$, and 11 people saved the number of employees.

\section{Conclusions}

A modern enterprise periodically needs to carry out technical re-equipment, as technologies develop and improve very quickly, advanced technologists are gradually crowding out the market for old technologies. The most important thing in this process is not to miss the time and understand in time that the company needs this process.

In order to understand whether the enterprise needs technical re-equipment, the management of the enterprise needs to build on the state of technical capacities for the period of research on this issue, it is necessary to assess the degree of deterioration of the equipment and understand what the management of the enterprise wants to receive from the new equipment, clearly indicating its goals. It often happens that when there is a fairly stable and stable position of the enterprise on the market, but at the same time the productivity of some units decreases, or the costs of production needs increase, technical re-equipment can have a positive impact on the technical and economic situation as a whole.

The moral and physical deterioration of technological equipment, the low efficiency of its use, reduced labor productivity, and high costs predetermined the technical re-equipment and modernization of the equipment of the workshops of a machine-building enterprise. However, the process of technological re-equipment is a process that requires a large number of investments, and a high level of professional training of specialists.

\section{Acknowledgments}

The work is performed according to the Russian Government Program of Competitive Growth of Kazan Federal University.

\section{References}

Amirov, K. F., \& Kurakov, L. P. M. (2002). Economics and law: dictionary. University and School.

Basova, A. S., \& Nuryyakhmetova, S. M. (2019). Development of innovative potential of a production enterprise. In A. S. Basova, \& S. M. Nuryyakhmetova (Eds.), Economics in a changing world: III All-Russian Economic Forum with international participation (pp. 174-177). Sat. scientific Articles, Kazan: Kazan publishing house. University.

Big Economic Dictionary. (2002). In A. N. Azriliyan (Ed.), Large Accounting Dictionary. M.: Institute of the New Economy.

Khisamova, E. D., RafisovichGaliev, L., \& Kodolova, I. A. (2017). Project quality assurance. Astra Salvensis, 2017, 603-618.

Nuryyakhmetova, S. M., Fathutdinova, O. A., \& Galiev, T. F. (2019). Improving the Efficiency of Freight Forwarding Companies Using System Restriction Theory. Journal of Economy and Entrepreneurship, 13, 10-713. 
Ostroshenko, V. V. (2005). A brief dictionary of the main forestry and economic terms. Ussuriysk: PSAA.

Perez, C. (2005). Technological revolutions and techno-economic paradigms / C. Perez. Working Papers in Technology Governance and Economic Dynamics no. 20 (p. 20). Tallinn: TallinnUniversity of Technology.

Reisenberg, B. A. (2006). Modern economic dictionary (4th ed., 5th ed.). Rev. and add. M.: Infra-M.

Scientific Encyclical. (n.d.). Modernization: a multi-subject. [Electronic resource]. Retrieved from http://ru.wikipedia.org/wiki

Susaraie, A. H., \& Sayahi, M. (2018). Study and recognition of the relationship between productivity pragmatics and quality of working life in Wood industry in Golestan province. Journal of Management and Accounting Studies, $6(1), 21-26$.

Yasin, E. (2009). The Role of innovation in the development of the world economy. Economic Issues, 9, 15-31. https://doi.org/10.32609/0042-8736-2009-9-15-31

\section{Copyrights}

Copyright for this article is retained by the author(s), with first publication rights granted to the journal.

This is an open-access article distributed under the terms and conditions of the Creative Commons Attribution license (http://creativecommons.org/licenses/by/4.0/). 